\title{
The Lipid Composition of Rat Liver
}

\author{
By G. S. GETZ*, W. BARTLEY, F. STIRPE $\dagger$, B. M. NOTTON AND A. RENSHAW \\ Department of Biochemistry and Medical Research Council, University of Oxford
}

(Received 18 November 1960)

In a previous publication (Getz \& Bartley, 1961) the fatty acid compositions of various intracellular compartments of the rat liver were investigated. This work has now been extended to the fatty acid composition of the different lipid classes of the liver. The data obtained will be used as a basis for comparison of the lipid composition of each of the cell components. This paper reports a compositional analysis of the whole rat liver.

\section{EXPERIMENTAL}

Fractionation of lipids on silicic acid. The techniques of preparation of the rat livers, of extraction of the lipid by chloroform-methanol $(2: 1, \mathrm{v} / \mathrm{v})$ and of determination of the fatty acid composition were as described by Getz \& Bartley (1961). The lipid extract was chromatographed on a silicic acid column ( $20 \mathrm{~g}$. of silicic acid) prepared according to the method of Hirsch \& Ahrens (1958), except that the Mallinckrodt silicic acid (mesh 100) used was not pre-ground before size-grading. The lipid load on the column was never more than $250 \mathrm{mg}$. of lipid, i.e. $12.5 \mathrm{mg}$./g. of adsorbent. Lipids were loaded on in light petroleum (b.p. $60-80^{\circ}$ ) and were eluted stepwise with the solvents shown in Table 1 . The elution data presented by Hirsch \& Ahrens (1958) for neutral lipids and by Hanahan, Dittmer \& Warashina (1957) for phospholipids were used as the guide for the choice of these solvent-elution sequences and volumes. However, it was necessary to determine the volumes of chloroformmethanol (3:2) required to separate the inositol from the lecithin. This was done by collecting fractions and measuring their phosphorus content. The separation is shown in Fig. 1. Hence the first $100 \mathrm{ml}$. of the chloroform-methanol (3:2) was collected separately from the remaining $400 \mathrm{ml}$.

* Present address: Department of Chemical Pathology, Witwatersrand University Medical School, Hospital Street, Hillbrow, Johannesburg, South Africa.

$\dagger$ Present address: Istituto di Patologia Generale dell' Università di Messina, Italy.
The composition of the silicic acid fractions was checked by paper chromatography on silicic acid-impregnated paper according to Marinetti, Erbland \& Kochen (1957). The results showed that the stepwise elution used produced the same mixtures of lipids as were found by Hanahan et al. (1957). Each of the solvent fractions was evaporated to dryness under $\mathrm{N}_{2}$ and made up to 10 or $25 \mathrm{ml}$. with chloroform before storage at $-20^{\circ}$ until required.

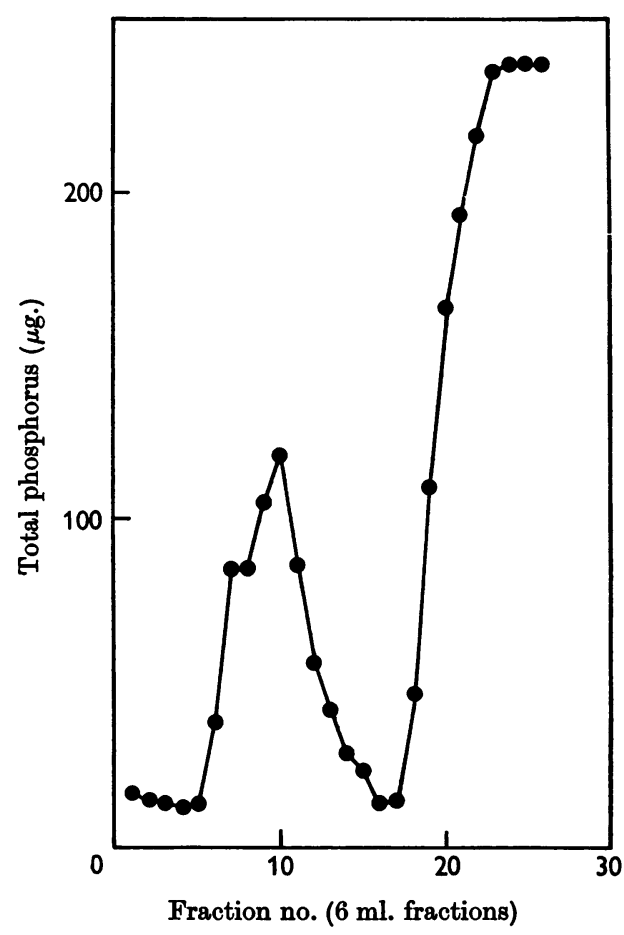

Fig. 1. Separation of lecithin and phosphatidylinositolcontaining fraction with chloroform-methanol (3:2).

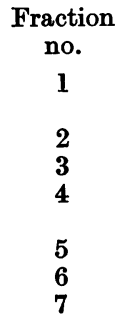

Table 1. Fractionation of lipids on silicic acid

\author{
Solvent mixture \\ $350 \mathrm{ml}$. of $1 \%$ ether in light petroleum (b.p. $\left.60-80^{\circ}\right)+$ \\ $60 \mathrm{ml}$. of $4 \%$ ether in light petroleum \\ $400 \mathrm{ml}$. of diethyl ether \\ $225 \mathrm{ml}$. of chloroform-methanol $(7: 1, \nabla / v)$ \\ $200 \mathrm{ml}$. of chloroform-methanol $(4: 1, \mathrm{v} / \mathrm{v})$ \\ $100 \mathrm{ml}$. of chloroform-methanol $(3: 2, \nabla / v)$ \\ $400 \mathrm{ml}$. of chloroform-methanol $(3: 2, \mathrm{v} / \mathrm{v})$ \\ $200 \mathrm{ml}$. of chloroform-methanol $(1: 4, \nabla / v)$
}

\section{Main fraction expected}

Cholesterol ester

Triglyceride

Serine phosphatide

Ethanolamine phosphatide + serine phosphatides

Inositol and serine phosphatide

Lecithin

Sphingomyelin 


\section{Table 2. Lipids from rat liver}

$22.9 \%$ of the rat-liver pulp consisted of solids precipitable with trichloroacetic acid. All results are given as $\mu$ moles/g. dry wt. of homogenate.

$\begin{array}{cc}\begin{array}{c}\text { Fraction } \\ \text { no. }\end{array} & \begin{array}{c}\text { Eluting solvent } \\ 1\end{array} \\ \begin{array}{c}1 \% \text { of diethyl ether in light } \\ \text { petroleum }\left(60-80^{\circ}\right) \text { followed by }\end{array} \\ 4 \% \text { of ether in light petroleum } \\ 2 & 100 \% \text { ether } \\ 3 & \text { Chloroform-methanol }(7: 1) \\ 4 & \text { Chloroform-methanol }(4: 1) \\ 5 & \text { Chloroform-methanol }(3: 2) \\ 6 & \text { Chloroform-methanol }(3: 2) \\ 7 & \text { Chloroform-methanol }(1: 4) \\ \text { Total in all fractions } \\ \text { Total from sample before fractionation } \\ \text { Recovery (\%) }\end{array}$

\begin{tabular}{|c|c|c|c|c|c|c|}
\hline $\begin{array}{c}\text { Lipid } \\
\text { esters in } \\
\text { fraction } \\
\text { ( } \mu \text { moles) }\end{array}$ & $\begin{array}{l}\text { Total phos } \\
\text { phate in } \\
\text { fraction } \\
\text { ( } \mu \text { moles) }\end{array}$ & $\begin{array}{l}\text { Ester/ } \\
\text { phosphate }\end{array}$ & $\begin{array}{c}\text { Total } \\
\text { choline } \\
\text { in } \\
\text { fraction } \\
\text { ( } \mu \text { moles })\end{array}$ & $\begin{array}{c}\text { Choline/ } \\
\text { phosphate }\end{array}$ & $\begin{array}{c}\text { Total } \\
\text { amino } N \\
\text { in } \\
\text { fraction } \\
(\mu \text { moles })\end{array}$ & $\begin{array}{l}\text { Amino N/ } \\
\text { phosphate }\end{array}$ \\
\hline $15 \cdot 1$ & - & - & - & - & - & - \\
\hline $67 \cdot 6$ & - & - & - & - & - & - \\
\hline $14 \cdot 7$ & 18.0 & 0.8 & - & - & 14.0 & 0.8 \\
\hline $55 \cdot 8$ & $28 \cdot 6$ & $2 \cdot 0$ & 0.23 & 0.008 & 27.8 & $1 \cdot 0$ \\
\hline $26 \cdot 6$ & 15.7 & 1.7 & 0.48 & 0.03 & 3.6 & 0.2 \\
\hline $159 \cdot 0$ & $88 \cdot 5$ & 1.8 & $64 \cdot 0$ & 0.7 & $2 \cdot 0$ & 0.02 \\
\hline $2 \cdot 4$ & $4 \cdot 15$ & 0.5 & 0.47 & 0.1 & 0.5 & 0.1 \\
\hline 341 & 155 & - & $65 \cdot 18$ & - & 48.0 & - \\
\hline 338 & 139.5 & - & - & - & - & - \\
\hline 100.05 & 111 & - & - & - & - & - \\
\hline
\end{tabular}

Barron \& Hanahan (1958) described an improved procedure for the fractionation of neutral lipids. This was used for a further batch of rat livers. The lipid extract was made with ethanol and ether as described by Getz \& Bartley (1961). The lipid extract was purified according to Folch, Lees \& Sloane-Stanley (1957). Unmodified Mallinckrodt silicic acid (mesh 100) was used for the separation and the column was prepared, packed and washed according to Barron \& Hanahan (1958). For elution, $15 \%$ of benzene in hexane was used for the sterol esters, $15 \%$ of diethyl ether in hexane for the triglycerides and diethyl ether alone for the remaining neutral glycerides. After the elution of the neutral lipid fractions, the phospholipids were eluted with chloroform-methanol mixtures in the sequence indicated above, with one exception. In this, chloroform-methanol (9:1) $(100 \mathrm{ml}$.) replaced the chloroform-methanol $(7: 1)$. The fraction eluted by this solvent is referred to in Tables 3 and 5 as 'non-polar phospholipid'. The chromatographic separation was followed by a semi-quantitative visual assessment of the esters on a small portion of each $10 \mathrm{ml}$. fraction collected on the fraction collector. The ester determination was that of Rapport \& Alonzo (1955) except that only $0.5 \mathrm{ml}$. of the ferric perchlorate was added to each tube to increase the sensitivity of the determination. Methyl esters of fatty acids were prepared by the inter-esterification and micro-sublimation technique of Stoffel, Chu \& Ahrens (1959).

Solvents. All solvents were AnalaR grade, except for ethanol and methanol, which were used without further purification, and hexane, which was the $67-69^{\circ}$ boiling fraction distilled from crude laboratory hexane.

Analytical methods. Measured portions of the fractions were taken for the determination of: (a) Lipid esters (method of Rapport \& Alonzo, 1955). (b) Total phosphorus (method of Berenblum \& Chain, 1938, as modified by Bartley, 1953). (c) Amino N (method of Cocking \& Yemm, 1954). Serine was used as standard and the result was multiplied by 10/9 to account for the lower colour yield for intact phosphatidylserine shown by Lea \& Rhodes (1955). (d) Choline (method of Wheeldon \& Collins, 1958, modified slightly in order to shorten the time required for preparing the hydrolysate). After hydrolysis, the hydrolysate was quantitatively filtered and the filtrate dried in vacuo to remove excess of $\mathrm{HCl}$. The residue was dissolved in less than $1 \mathrm{ml}$. of water and the solution was transferred to a graduated tube. After neutralization with $\mathrm{N}-\mathrm{NaOH}$ to $\mathrm{pH}$ 6-7, the solution was extracted twice with diethyl ether to remove fatty acid and the volume was made to $1 \mathrm{ml}$. A sample $(0.5 \mathrm{ml}$.) of this solution was taken for the choline estimation but $0.5 \mathrm{ml}$. of phosphomolybdate was used in place of the $0 \cdot 1 \mathrm{ml}$. suggested by Wheeldon \& Collins (1958). (e) Cholesterol (method of Zlatkis, Zak \& Boyle, 1953, as modified by Henry, 1957). ( $f$ ) Glycerol (method of Hanahan \& Olley, 1958, $2 \mathrm{~N}-\mathrm{HCl}$ being used for hydrolysis). More usually the glycerol was estimated in the watersoluble residue remaining after the light-petroleum extraction of the inter-esterification reaction mixture but without removing the $\mathrm{HCl}$.

Gas-liquid chromatography. The techniques were those described by Getz \& Bartley (1961).

\section{RESULTS}

For the fractionation of all the lipid classes of the liver $10.8 \mathrm{~g}$. of liver pulp was extracted. This yielded $2.47 \mathrm{~g}$. of material precipitable by trichloroacetic acid. The total extractable lipids constituted $18.55 \%$ of this dry weight. For the fractionation of the neutral lipids $9 \cdot 44 \mathrm{~g}$. of liver pulp was extracted. The dry weight was $2 \cdot 11 \mathrm{~g}$. and the lipid was $23.4 \%$ of this dry weight. The results of the silicic acid fractionations are given in Tables 2 and 3 , and of the fatty acid determinations in Tables 4 and 5. Table 2 shows that phosphatidylcholine is the major lipid of the rat liver. It is assumed in silicic acid fraction 5 that the difference between the total phosphate and the sum of amino nitrogen and choline in this fraction is due to phosphoinositides. Some $70 \%$ of the total phosphate in this fraction when calculated on this basis is accounted for as phosphoinositides. The conclusion is supported by the fact that stearate and arachidonate predominate amongst the fatty

Bioch. 1961, 80 
Table 3. Neutral lipid from livers of young rats

22.3\% of the rat-liver pulp consisted of solids precipitable with trichloroacetic acid. All results are given as $\mu$ moles/g. dry wt. of homogenate.

\begin{tabular}{|c|c|c|c|c|c|c|c|c|}
\hline $\begin{array}{l}\text { Fraction } \\
\text { no. }\end{array}$ & Eluting solvent & $\begin{array}{l}\text { Lipid } \\
\text { esters in } \\
\text { fraction } \\
\text { ( } \mu \text { moles) }\end{array}$ & $\begin{array}{l}\text { Total phos- } \\
\text { phate in } \\
\text { fraction } \\
\text { ( } \mu \text { moles })\end{array}$ & $\begin{array}{c}\text { Total } \\
\text { amino } N \\
\text { in fraction } \\
(\mu \text { mole })\end{array}$ & $\begin{array}{c}\text { Total } \\
\text { glycerol } \\
\text { in fraction } \\
(\mu \text { moles })\end{array}$ & $\begin{array}{c}\text { Ester/ } \\
\text { glycerol }\end{array}$ & $\begin{array}{l}\text { Ester/ } \\
\text { phos- } \\
\text { phate }\end{array}$ & $\begin{array}{c}\text { Amino N/ } \\
\text { phos- } \\
\text { phate }\end{array}$ \\
\hline 1 & $\begin{array}{l}15 \% \text { of benzene in } \\
\text { hexane }\end{array}$ & $5 \cdot 12$ & - & $0 \cdot 13$ & 0.19 & $23 \cdot 7$ & - & - \\
\hline 2 & $\begin{array}{l}15 \% \text { of hexane in } \\
\text { ether }\end{array}$ & $35 \cdot 6$ & $0 \cdot 13$ & 0.39 & $17 \cdot 7$ & 2.01 & - & - \\
\hline 3 & $100 \%$ ether & $7 \cdot 8$ & $0 \cdot 18$ & 0.57 & $3 \cdot 24$ & $2 \cdot 42$ & - & - \\
\hline 4 & $\begin{array}{l}\text { Chloroform- } \\
\text { methanol }(9: 1) \\
\text { (non-polar phospho- } \\
\text { lipid) }\end{array}$ & $20 \cdot 0$ & 3.96 & $0 \cdot 66$ & - & - & $5 \cdot 04$ & $0 \cdot 17$ \\
\hline
\end{tabular}

Table 4. Fatty acid composition of lipids from rat liver

'Present' indicates that the fatty acid is present as less than $0.02 \%$ of the total acids. Analysis of the nonfatty acid portion of the lipids is given in Table 2. For further details see text. Results are given as g./100 g. of fatty acid methyl ester. Fatty acid designation: br., branched; hbr., highly branched; uns., unsaturated acid (no. of double bonds unknown); a, acids identified by comparison with authentic standards; b, acids identified by comparison of their retention volumes with those in the literature. Remaining acids are designated solely on the basis of retention volumes on two stationary phases.

Main lipid class in material analysed

\begin{tabular}{|c|c|c|c|c|c|c|c|c|c|}
\hline & & & & & & & & & \\
\hline Acid & $\begin{array}{l}\text { Total } \\
\text { esters }\end{array}$ & $\begin{array}{l}\text { Sterol } \\
\text { esters }\end{array}$ & $\begin{array}{c}\text { Tri- } \\
\text { glycerides }\end{array}$ & $\begin{array}{c}\text { Serine } \\
\text { phosphatide }\end{array}$ & $\begin{array}{l}\text { Serine }+ \\
\text { ethanol- } \\
\text { amine } \\
\text { phos- } \\
\text { phatides }\end{array}$ & $\begin{array}{c}\text { Serine } \\
\text { phos- } \\
\text { phatides + } \\
\text { inositides }\end{array}$ & Lecithin & $\begin{array}{c}\text { Sphingo- } \\
\text { myelin }\end{array}$ & $\begin{array}{l}\text { Extracted } \\
\text { free acid }\end{array}$ \\
\hline 9-br. & 0.05 & - & - & - & - & - & - & - & - \\
\hline $11-\mathrm{br}$. & - & Present & Present & - & - & 0.02 & - & - & - \\
\hline 12-br. & - & - & 0.04 & - & - & - & - & Present & - \\
\hline a $12-0$ & 0.06 & Present & $0 \cdot 15$ & Present & Present & Present & - & 0.51 & 0.31 \\
\hline $12-1$ & - & - & Present & - & - & - & - & - & - \\
\hline 13-br. & - & 0.02 & - & - & - & 0.06 & - & Present & - \\
\hline b 13-0 & 0.08 & - & Present & - & Present & - & - & & - \\
\hline a 14-0 & 0.82 & 0.70 & 1.05 & 0.86 & 0.08 & 0.05 & 0.46 & 0.71 & 0.40 \\
\hline 14-br. & - & - & - & -. & Present & Present & - & Present & 0.61 \\
\hline 14-br. & - & - & - & - & Present & - & - & & - \\
\hline b 14-1 & 0.04 & 0.06 & Present & 0.20 & 0.04 & - & - & 0.99 & - \\
\hline b $15-0$ & 0.50 & 0.58 & 0.57 & 0.61 & $0 \cdot 17$ & - & 0.34 & 0.93 & 0.78 \\
\hline 15 -br. & - & 0.08 & Present & - & Present & 0.06 & - & 0.13 & - \\
\hline 15-br. & 0.21 & 0.64 & - & 0.33 & - & Present & - & - & - \\
\hline a $16-0$ & $25 \cdot 00$ & 26.05 & $25 \cdot 85$ & $22 \cdot 80$ & $25 \cdot 70$ & $12 \cdot 63$ & $29 \cdot 70$ & $20 \cdot 40$ & $30 \cdot 60$ \\
\hline b 16-1 & 1.90 & 1.92 & 2.92 & $2 \cdot 24$ & 0.47 & $0 \cdot 30$ & 0.96 & 0.99 & $6 \cdot 77^{*}$ \\
\hline 16-br. & - & $0 \cdot 42$ & Present & $0 \cdot 15$ & Present & - & - & Present & $0 \cdot 44$ \\
\hline b 17-0 & $0 \cdot 25$ & 0.47 & Present & 0.83 & 0.72 & 0.70 & 0.63 & Present & 0.89 \\
\hline 17-br. & - & 0.52 & Present & 0.36 & 0.08 & 0.15 & 0.38 & - & - \\
\hline 18-hbr. & - & 0.35 & Present & - & 0.07 & - & 0.15 & - & - \\
\hline a $18-0$ & 11.90 & $2 \cdot 68$ & 1.47 & $15 \cdot 25$ & 20.80 & $38 \cdot 60$ & 16.80 & $11 \cdot 40$ & $10 \cdot 45$ \\
\hline a $18-1$ & 20.50 & $\mathbf{4 0} \cdot 70$ & 28.50 & 15.00 & $8 \cdot 11$ & $5 \cdot 47$ & 10.42 & $11 \cdot 40$ & $25 \cdot 00$ \\
\hline a 18-2 & 22.80 & $17 \cdot 70$ & 29.60 & 30.85 & $13 \cdot 40$ & $5 \cdot 78$ & 16.75 & $49 \cdot 60^{*}$ & $19 \cdot 45$ \\
\hline a 18-3 & - & - & 0.86 & - & - & - & - & - & - \\
\hline 19-br. & - & - & - & - & $0 \cdot 13$ & 0.63 & - & - & - \\
\hline b $20-1$ & $0 \cdot 30$ & 0.31 & - & - & Present & - & - & - & - \\
\hline b $20-2$ & - & - & Present & Present & Present & 0.74 & - & Present & - \\
\hline b $20-3$ & 0.20 & 0.49 & 0.30 & 0.77 & 1.07 & 1.86 & 1.54 & Present & - \\
\hline b 20.4 & $9 \cdot 80$ & 1.86 & $1 \cdot 10$ & $7 \cdot 60$ & $19 \cdot 85$ & $28 \cdot 20$ & $18 \cdot 30$ & 3.04 & 4.35 \\
\hline b $20-5$ & 0.54 & - & $1 \cdot 34$ & - & - & - & - & - & - \\
\hline b 22-5 & 0.50 & 0.30 & $2 \cdot 78$ & - & 0.90 & 0.91 & Present & - & - \\
\hline b 22-6 & 3.71 & 3.42 & 2.93 & 2.00 & 8.50 & $3 \cdot 86$ & $\mathbf{3 . 4 3}$ & - & - \\
\hline 24-uns. & 0.67 & - & 0.69 & - & - & - & - & - & - \\
\hline
\end{tabular}

\footnotetext{
* Peak contains more than one compound.
} 
Table 5. Fatty acid composition of neutral lipids from young rat liver

Details are as given in Table 3 and text. Results are given as g./100 g. of fatty acid methyl ester. Fatty acid designation ( $a$ and $b$ ) is as given in Table 4.

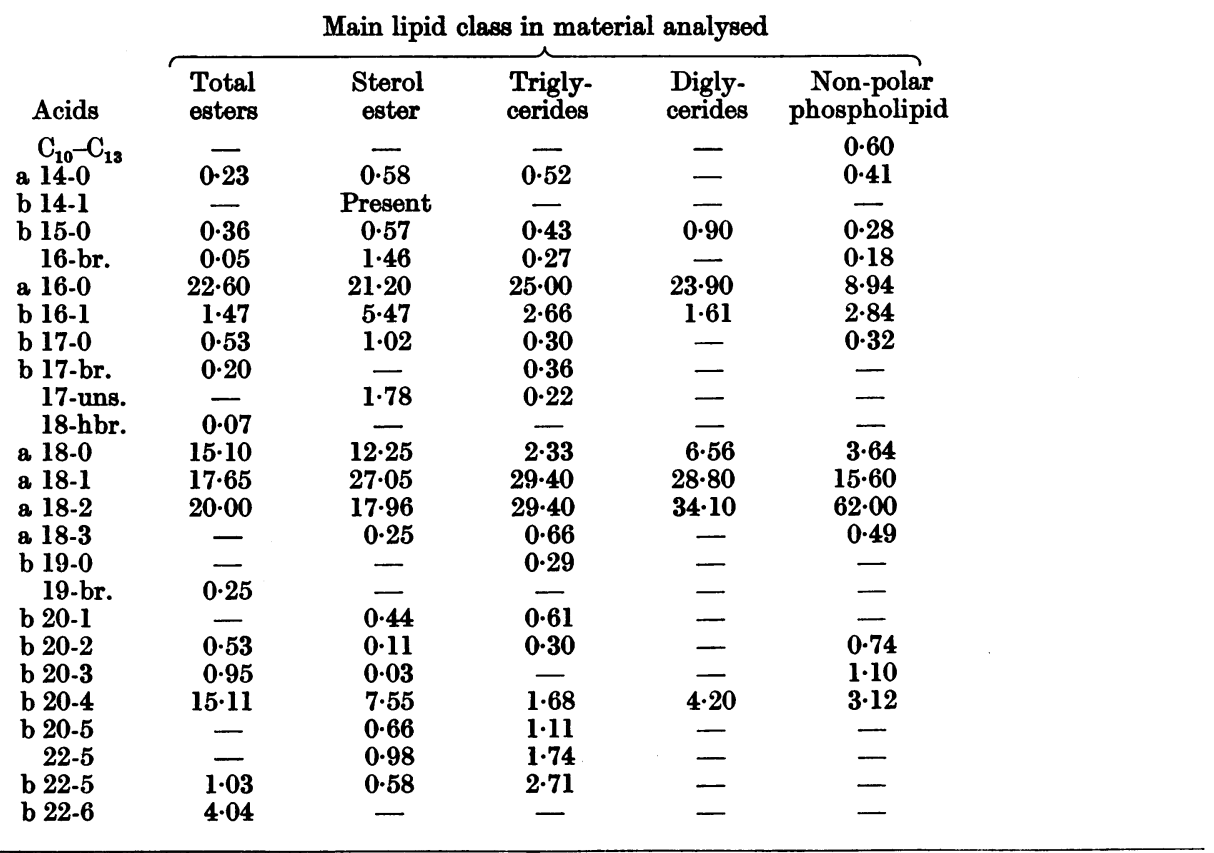

acids in this fraction. These two fatty acids have already been reported as major constituents of phosphoinositides (Dittmer \& Hanahan, 1959). The low choline: phosphorus ratio in the lecithin fraction has no obvious explanation.

The fatty acid-ester pattern of each lipid class showed characteristic differences. One point of similarity was the rather similar percentage of palmitate in each lipid class with the exception of the inositide, which had only about half the palmitate concentration ( $12 \%$ compared with about $25 \%$ ). The neutral-lipid fractions were characterized by high palmitoleate and high oleate but low stearate and arachidonate when compared with the phospholipids. In the fractionation of the neutral lipids by the method of Barron \& Hanahan (1958), the triglycerides found were much less $(72 \mu$ moles of triglyceride/g. of fat compared with $147 \mu$ moles of triglyceride/g. of fat). There was also less sterol ester $(10 \cdot 1 \mu \mathrm{moles} / \mathrm{g}$. of fat compared with $33 \mu$ moles/g, of fat). This may be due to the younger age of the rats used in the second fractionation. The sterol fatty acids in the second extraction have a higher palmitoleate, stearate and arachidonate than in the fractionation described in Table 2. Oleate was the predominating acid in the sterol esters. The triglyceride fraction was unusual in having almost equal quantities of docosapentaenoate and docosahexaenoate (Table 4).
The non-polar phospholipid has a low amino nitrogen/phosphorus ratio (Table 3) and a very high content of unsaturated fatty acid, particularly linoleic acid (18-2). These analytical features are consistent with a fraction which contains a large amount of 'Cardiolipin' (Gray \& Macfarlane, 1958; Getz \& Bartley, 1959). The remaining phospholipids recovered from the second batch of rat livers were similar, on analysis, to those from the first batch and have therefore not been included in Tables 3 and 5. In this case, however, the lecithin fraction was analysed by the mild alkaline hydrolysis and paper-chromatography method of Dawson (1960); $96 \%$ of the total phosphorus of the fraction was found as glycerylphosphorylcholine $\left(R_{F}, 0.77\right.$ in phenol-acetic acid-ethanol-water solvent).

The phospholipids generally were low in oleate but contained large amounts of stearate and arachidonate, particularly in the inositide fraction. A high linoleate content was found in the triglyceride in the non-polar phospholipid fraction and in the sphingomyelin fraction.

The free fatty acid fraction (Table 3) was obtained from the triglyceride fraction by extraction with methanolic alkali $(0.5 \%$ of potassium carbonate in $50 \%$ methanol) and subsequent esterification. The amount of free acid found was 6.55 $\mu \mathrm{moles} / \mathrm{g}$. dry wt. of liver. Table 3 shows that its composition differs somewhat from the triglycerides associated with it. 


\section{DISCUSSION}

The distribution of phosphorus between lecithin and other phospholipids reported in this paper accords well with that given by Hanahan et al. (1957), and with that tabulated by Dawson (1957) in his review of animal phospholipids. The mean value of $35.8 \mu$ moles of phospholipid/g. wet wt. of liver is to be compared with $39 \mu$ moles/g. wet wt. given by Artom (1945). Lecithin and sphingomyelin constituted $60 \%(23.4 \mu \mathrm{moles} / \mathrm{g}$. dry wt.) of the phospholipid. This corresponds closely with our values.

The fatty acid composition of the liver-lipid fractions is similar to those reported by Macfarlane, Gray \& Wheeldon (1960) and Dittmer \& Hanahan (1959). The latter authors used reversed-phase column chromatography for the separation of fatty acids and their sterol ester fraction has a higher stearate and arachidonate than ours. Dittmer \& Hanahan did not estimate the minor fatty acids individually and this may account for the discrepancy. Generally, similar results have also been obtained with alkali isomerization for the estimation of unsaturated fatty acids of rat-liver cholesterol ester, triglyceride and phospholipid by Okey \& Harris (1958), except that our values for dienoic acids and tetraenoic acids are somewhat lower in each case.

Studies of fatty acid composition of liver lipids have been made in other species. For instance, Bruce, Shorland \& Jessop (1952) studied horse liver and found a partitioning of palmitic acid, stearic acid and unsaturated $\mathrm{C}_{18}$ and $\mathrm{C}_{20}$ acids between neutral glycerides and phospholipids that was broadly similar to that found in this study, except that the horse liver contained much more linolenic acid than did rat liver. Linolenic (18-3) acid was present in only very small amounts in the rat liver and especially in the triglycerides, although it was present in the diet (Getz \& Bartley, 1961). Hilditch $\&$ Shorland (1937) have also reported a similar distribution of fatty acids between neutral glyceride and phospholipid fatty acids of the livers of the ox, cow, sheep and pig, with some small exceptions. The pig- and sheep-liver glycerides have higher stearate and arachidonate than is normally found in neutral glycerides, and the cow-liver phosphatide had a surprisingly small quantity of unsaturated $C_{20}$ acid.

In general, however, all studies including this one indicate the presence of high palmitate, and $\mathrm{C}_{18}$ unsaturated acids with low stearate and $\mathrm{C}_{20}$ unsaturated acids in neutral-lipid fractions, whereas phospholipids are characterized by relatively high stearate and $\mathrm{C}_{20}-\mathrm{C}_{22}$ polyunsaturated acids together with low $\mathrm{C}_{18}$ unsaturated acids. There is, however, a considerable variation in the fatty acid composition of the individual phospholipids. This is in contrast with similarity of fatty acid composition within the cell organelle. Thus irrespective of the location within the cell, the phospholipid tends to have the same fatty acid composition.

\section{SUMMARY}

1. The lipids of the rat liver have been fractionated into cholesterol esters, triglycerides, serine phosphatides, ethanolamine phosphatides, inositol phosphatides, lecithin and sphingomyelin, and the fatty acid content of the isolated lipids has been measured.

2. More than $50 \%$ of the lipid phosphorus was found in the phosphatidylcholine fraction. Most of the neutral lipid was in the form of triglycerides.

3. The neutral lipids were high in palmitate and $\mathrm{C}_{18}$ unsaturated fatty acids whereas the phospholipids had relatively high stearate and $\mathrm{C}_{20}-\mathrm{C}_{22}$ polyunsaturated fatty acids with low $\mathrm{C}_{18}$ unsaturated acids.

We wish to thank Professor Sir Hans Krebs, F.R.S., for his interest in the work and Dr D. S. Robinson for his helpful criticism. The work was aided by grants from the National Institutes of Health, United States Public Health Service and the Rockefeller Foundation. F.S. wishes to thank the Istituto di Patologia Generale dell' Università di Messina, Italy, for leave of absence in carrying out this research. G.S.G. held a Nuffield Demonstratorship during the period of the research and wishes to thank the Nuffield Dominions Trust for this financial support.

\section{REFERENCES}

Artom, C. (1945). J. biol. Chem. 157, 595.

Barron, E. J. \& Hanahan, D. J. (1958). J. biol. Chem. 231, 493.

Bartley, W. (1953). Biochem. J. 54, 677.

Berenblum, I. \& Chain, E. (1938). Biochem. J. 32, 295.

Bruce, L. W., Shorland, F. B. \& Jessop, A. S. (1952). Biochem. J. 52, 400.

Cocking, E. C. \& Yemm, E. W. (1954). Biochem. J. 58, xii.

Dawson, R. M. C. (1957). Biol. Rev. 32, 188.

Dawson, R. M. C. (1960). Biochem. J. 75, 45.

Dittmer, J. C. \& Hanahan, D. J. (1959). J. biol. Chem. 234, 1976.

Folch, J., Lees, M. \& Sloane-Stanley, G. H. (1957). J. biol. Chem. 226, 497.

Getz, G. S. \& Bartley, W. (1959). Nature, Lond., 184, 1229.

Getz, G. S. \& Bartley, W. (1961). Biochem. J. 78, 307.

Gray, G. M. \& Macfarlane, M. G. (1958). Biochem. J. 70, 409.

Hanahan, D. J., Dittmer, J. C. \& Warashina, E. (1957). J. biol. Chem. 228, 685.

Hanahan, D. J. \& Olley, J. N. (1958). J. biol. Chem. 231, 813.

Henry, A. A. (1957). Analyst, 82, 286.

Hilditch, T. P. \& Shorland, F. B. (1937). Biochem. J. 31, 1499. 
Hirsch, J. \& Ahrens, E. H., jun. (1958). J. biol. Chem. 233, 311.

Lea, C. H. \& Rhodes, D. N. (1955). Biochim. biophys. Acta, $17,416$.

Macfarlane, M. G., Gray, G. M. \& Wheeldon, L. W. (1960). Biochem. J. 77, 626.

Marinetti, G. V., Erbland, J. \& Kochen, J. (1957). Fed. Proc. 16, 837.
Okey, R. \& Harris, A. G. (1958). Arch. Biochem. Biophys. 75, 536.

Rapport, M. M. \& Alonzo, N. (1955). J. biol. Chem. 217, 193.

Stoffel, W., Chu, F. \& Ahrens, E. H., jun. (1959). Analyt. Chem. 31, 307.

Wheeldon, F. W. \& Collins, F. D. (1958). Biochem. J.70, 43.

Zlatkis, A., Zak, B. \& Boyle, G. J. (1953). J. Lab. clin. Med. 41, 486.

\title{
The Mechanism of Fructose Formation in Goat Placenta with Special Reference to the Possible Involvement of Sorbitol or of Phosphoric Acid Esters
}

\author{
BY M. W. NEIL, D. G. WALKER* AND F. L. WARREN \\ Department of Biochemistry, London Hospital Medical College, Turner Street, London, E. 1
}

(Received 12 December 1960)

The presence of fructose in the foetal blood of ungulates and its virtual absence from the maternal blood have been frequently observed (e.g. Goodwin, 1956). Huggett, Warren \& Warren (1951) provided evidence, by means of both infusion and perfusion experiments, that the placenta was the site of fructose formation in the sheep. Walker (1960) used the infusion technique with the separation of one of twin foetuses to demonstrate that the placenta is a site of fructose formation from glucose in the goat also. Perfusion experiments are reported in the present paper which confirm this finding for the goat.

The mechanisms of fructose formation from glucose remains obscure. Two hypotheses to explain fructose formation are considered in this paper. One, put forward by Winterton (1949), suggested that fructose was formed in sheep placenta by the action of a phosphatase on a fructose phosphorio acid ester. The second hypothesis, that fructose might be formed from glucose via sorbitol, arose from the observation by Williams-Ashman \& Banks (1954) that sorbitol dehydrogenase (ketose reductase) was present in the seminal vesicles of the rat and the suggestion that this could be part of a mechanism for the formation of fructose by this tissue. That fructose is indeed formed from glucose via sorbitol in sheep seminal vesicles has recently been convincingly demonstrated by Hers $(1960 a, b)$.

The results reported in this paper supply some evidence alongside which these hypotheses may be considered. A preliminary account of some of this work was given by Neil, Walker \& Warren (1957).

* Present address: Department of Biochemistry, University of Birmingham, Edgbaston, Birmingham 15.

\section{EXPERIMENTAL}

Details concerning goats, surgical procedure, infusion of sugars (and, in this paper, sorbitol), collection of blood samples, chromatography of blood extracts and the determination of sugars have been given by Walker (1960).

Perfusion of the placenta. A Dalo-Schuster pump unit was employed. In the initial experiments heparinized maternal-goat plasma was used as perfusion fluid, but more satisfactory results were obtained later with a dextransaline solution having the following composition: dextran, $5 \cdot 1 \%(\mathrm{w} / \mathrm{v}) ; \mathrm{NaCl}, 0.76 \% ; \mathrm{KHCO}_{3}, 0.24 \%$; equilibrated with $\mathrm{O}_{2}+\mathrm{CO}_{2}(95: 5)$ at $37^{\circ}$. The umbilical-cord vessels were dissected and one vein and one artery cannulated. Perfusion into the artery was started, and the remaining pair of uncannulated vessels immediately ligatured. The foetus was then removed by cutting the cord. The perfusion fluid was sampled at intervals for sugar analyses.

Detection of sorbitol-dehydrogenase activity. Homogenates of placental tissue $(10 \%$ in $0.25 \mathrm{M}$-sucrose) or extracts of acetone-dried powders of placental tissue were assayed by the method of Blakley (1951) as described by Wolff (1955). The advisability of using whole homogenates where possible for detection of the enzyme was indicated by Blakley (1951). He found, using the Warburg technique, that extracts of rat kidney, for example, failed to oxidize sorbitol, whereas a whole homogenate of this tissue did so. In this work the Thunberg-tube technique was chosen as a rapid and simple method for detection of the enzyme with whole homogenates.

The tubes contained the following mixture: potassium phosphate buffer, $1.0 \mathrm{ml}$., $0.1 \mathrm{M}, \mathrm{pH} 8.0$; sorbitol, $0.2 \mathrm{ml}$., $0.1 \mathrm{~m}$; diphosphopyridine nucleotide (DPN), $0.1 \mathrm{ml} ., 5 \mathrm{~mm}$; sodium malonate, $0.3 \mathrm{ml}$., $1.0 \mathrm{M}$; nicotinamide, $0.3 \mathrm{ml}$., $1.0 \mathrm{M}$; methylene blue, 0.1 or $0.3 \mathrm{ml}$., $1 \mathrm{~mm}$; placental homogenate, 0.5 or $0.25 \mathrm{ml}$., $10 \%$ in water in most experiments; water to $3.0 \mathrm{ml}$. Control tubes contained water in place of sorbitol solution. The tubes were evacuated and incubated at $37^{\circ}$. Enzyme activity was expressed as the 